\title{
Identification of Polymorphisms of Gene CSN2 of B Casein in Greek Cow Breeds (Holstein) by Restriction Fragment Length Polymorphism
}

\author{
Despina Vougiouklaki ${ }^{1}$, Dionysios Antonopoulos ${ }^{1}$, Stella Allexeli ${ }^{1}$ \& Dimitra Houhoula ${ }^{1}$ \\ ${ }^{1}$ Department of Food Science and Technology, Faculty of Food Sciences, University of West Attica, Athens, \\ Greece \\ Correspondence: Dimitra Houhoula, Department of Food Science and Technology, Faculty of Food Sciences, \\ University of West Attica, Str. Agiou Spyridonos 2,12243 Egaleo, Athens, Greece. Tel: 30-695-154-0752. E-mail: \\ dhouhoula@uniwa.gr
}

Received: August 20, 2020

Accepted: September 21, 2020

Online Published: October 15, 2020

doi:10.5539/jas.v12n11p32

URL: https://doi.org/10.5539/jas.v12n11p32

\begin{abstract}
The research focused to detect and identify genetic polymorphisms in exon 7 of the $\beta$-casein CSN2 gene in blood samples from Greek Holstein cows. For this purpose, DNA was extracted from 120 blood samples of cows. The desired region of exon 7 was amplified by PCR, resulting in a 121 bp product. The PCR product was digested by restriction fragment length polymorphism (RFLP) method. The results suggest that the A1A2 genotype prevails over the others. Specifically, of the 120 cattle, 72 showed triple bands of $121 \mathrm{bp}, 86 \mathrm{bp}$, and $35 \mathrm{bp}$ indicating the A1A2 genotype. The 42 cattle showed a single band at $121 \mathrm{bp}$, indicating that they carried the A1A1 genotype. The remaining 6 showed only two bands of 86 and $35 \mathrm{bps}$, indicating that they carried the A2A2 genotype. In the total population of heterozygotes A1A2-0.60 were the most frequent, while homozygotes A2A2-0.06 were the least frequent ones. This suggests a slight superiority of allele A- 0.65 .
\end{abstract}

Keywords: $\beta$-casein, b-casomorphin-7, polymorphism, PCR-RFLP

\section{Introduction}

Milk has always played an important role in the human diet, as it is considered a considerable source of all essential amino-acids, vitamins, metals, minerals. More specifically, bovine milk contains a total of $3.5 \%$ protein (Davoodi et al., 2016). Proteins are one of the most important milk components, that have received the greatest attention due to their recognized health-related properties. Casein (as1, as 2 , beta, kappa) accounts for $80 \%$ of the total protein content (Haug, Høstmark, \& Harstad, 2007). The remaining $20 \%$ of the protein content is the serum protein (Davoodi et al., 2016). Beta casein's gene (CSN2) belongs to the cluster of four casein genes located on chromosome 6 (Ferretti, Leone, \& Sgaramella, 1990; Jann, Ceriotti, Caroli, \& Erhardt, 2002; Kumar et al., 2019). It is known that beta casein has 12 genetic variants, (A1, A2, A3, B, C, D, E, F, G, H1, H2 and I) (Kumar et al., 2019; Massella et al., 2017; Sebastiani et al., 2020). Among them, the most frequent genetic variants of CSN2 are A1 and A2 (Balteanu, Vlaic, Suteu, \& Carsai, 2010; Cieślińska et al., 2012; Dinc, Ozkan, Koban, \& Togan, 2013). The variants $A 1$ and $A 2$ are composed of 209 amino-acids. The A1 variant differs to the $A 2$ at one amino acid of the amino acid chain. More specifically, proline (codon CCT) on the 67th position (A2 variant) has been replaced by histidine (codon CAT) (A1 variant) (Kumar et al., 2019; Miluchová et al., 2014; Massella et al., 2017). This mutation has an effect on the proteolytic digestion of the primary protein structure, leading to the production of different peptides. B-casomorphin is a bioactive peptide produced from $\beta$-casein variants A1 and has a significant opioid activity (Brooke-Taylor, Dwyer, Woodford, \& Kost, 2017; Massella et al., 2017). BCM-7 is a small molecule that can infiltrate blood circulation more easily, and cause various health problems, such as gastrointestinal disorders, insulin-dependent diabetes, atherosclerosis, ischemic heart diseases and sudden infant death syndrome (Brooke-Taylor et al., 2017; Boztepe, Aytekin, \& Şahin, 2018; Elliott, Harris, Hill, Bibby, \& Wasmuth, 1999; Kumar et al., 2019; McLachlan, 2001; Sun et al., 2003). To our knowledge, there is a lack of genetic polymorphism of b-casein in cows that are bred in Greece. The aim of this study was to identify the frequency and type of genetic polymorphisms in exon 7 of the $\beta$-casein CSN2 gene in blood samples from Greek cows Breeds (Holstein). 


\section{Materials and Methods}

\subsection{Experimental Animals and Farms}

A total of 120 Greek Holstein-Friesian cows studied in this research were taken from two different regions of Greece. The first farm was located in Korinthia, an area of the northeastern Peloponnese and the second in Larissa, a city in Thessaly. A representative genotype and correlation study was performed for the A1/A2 sites of the $\beta$-casein gene in Greek cows in the country.

\subsection{Institutional Animal Care and Use Committee (IACUC)}

Animal blood sampling was based on the 2010/63 EU guidelines of European community and council on the protection of animals used for scientific purposes. According to directive article 1, paragraph 5, element $\mathrm{f}$, 'practices not likely to cause pain, suffering, distress or lasting harm equivalent to, or higher than, that caused by the introduction of a needle in accordance with good veterinary practice'.

\subsection{Selection and Preparation of Control Samples}

Blood samples from Cow identified as A2A2 (characterised as control samples) were acquired directly from the animals and were kept at $-18^{\circ} \mathrm{C}$ until the analysis.

\subsection{Selection and Preparation of Blood Samples}

During the study period (September 2019 to March 2020) a total of 120 blood samples were collected from Holstein-Friesian cows, in tubes containing Ethylene diamine tetra-acetic acid (EDTA) and were kept at $-18{ }^{\circ} \mathrm{C}$ until the analysis.

\subsection{DNA Isolation}

$350 \mu \mathrm{l}$ of blood from each cow was used. The control samples were centrifugated $(10$ minutes at $12000 \times \mathrm{g})$ in order to obtain a pellet. The DNA was extracted by using NucleoSpin Blood kit, by Machery-Nagel. According to the manufacturer's instructions with a modification of an overnight incubation with the Lysis Buffer and the Proteinase $\mathrm{K}$ at $65{ }^{\circ} \mathrm{C}$ instead an incubation of the $30 \mathrm{~min}$ incubation. The extracted DNA was quantified spectrophotometrically at $260 \mathrm{~nm}$.

\subsection{PCR Amplification and Restriction Fragment Length Polymorphism Detection}

The region of exon 7 of CSN2 was amplified by PCR. The DNA primers used for the PCR amplification, were forward primer 5'-CCTTCTTTCCAGGATGAACTC CAGG-3' and reverse primer 5'-GAGTAAGAGGAGGG ATGTTTTGTGGGAGGCTCT-3'. DNA primers described by Saran, Gurao, Joshi, and Kashyap (2019). The PCR mix composed: $0.3 \mu \mathrm{l}$ of primers Csn4F and Csndde4R (HS ReadyMix and dye, KAPABIOSTSTEMS). The amplification was conducted by a thermal cycler ( 96 Well thermal cycler applied Biosystems, Singapore), as follows: The chosen temperatures were set at $94-96^{\circ} \mathrm{C}$ for $4 \mathrm{~min}, 35$ cycles of $95^{\circ} \mathrm{C}$ for $60 \mathrm{sec}, 58^{\circ} \mathrm{C}$ for $60 \mathrm{sec}$, $72{ }^{\circ} \mathrm{C}$ for $60 \mathrm{sec}$, and final extension of $7 \mathrm{~min}$ at $72{ }^{\circ} \mathrm{C}$, for Csn4F and Csndde4R. PCR products were separated in $2 \%$ agarose gel. The yield and specificity of the PCR products were evaluated after electrophoresis in $2 \%$ agarose gel stained with ethidium bromide $(0.5 \mu \mathrm{g} / \mathrm{ml})$ and documented under UV illumination using MiniBIS Pro device (DNR Bio-Imaging Systems Ltd., Israel) producing a $121 \mathrm{bp}$ fragment of the CSN2 gene. The PCR products were then digested with $5 \mathrm{U}$ of DdeI, and the restriction digestion fragments were analyzed by electrophoresis on a $3 \%$ agarose gel, in order to identify the genotype. The RFLP pattern is used to identify the genotypes as A1A1 (121 bp), A2A2 (86 and $35 \mathrm{bp)}$ or A1A2 (121, 86 and $35 \mathrm{bp}$ ).

Each A2A2 homozygote was confirmed a second time via a genotyping procedure. Genetic equilibrium of the examined population was estimated due to the Hardy-Weinberg principle and tested with the chi-square test (http://www.dr-petrek.eu/documents/HWE.xls). The study was conducted with compliance to local bioethics committee guidelines (18/2013).

\section{Results}

Genomic DNA was isolated from 120 blood samples from Holstein-Friesian breed cows. The extracted DNA collected was checked for its concentration and purity by photometry. All samples had a concentration of 80-120 $\mathrm{ng} / \mu \mathrm{l}$ and a purity of $1.5-1.9 \mathrm{ng} / \mu \mathrm{l}$. Subsequent amplification of exon $7 \mathrm{of} \beta$-casein was followed by the appropriate primers. Electrophoresis on $1.8 \%$ agarose gel was performed to verify the method. A PCR of a known molecular weight of $50 \mathrm{bp}$ (ladder) was added during the electrophoresis of the PCR products to calculate the molecular size of the fragment. The amplified segments were $121 \mathrm{bp}$ in size. The figure below shows a typical result of a PCR amplification of the portion of the gene studied. All the 120 blood samples had the amplified size. 


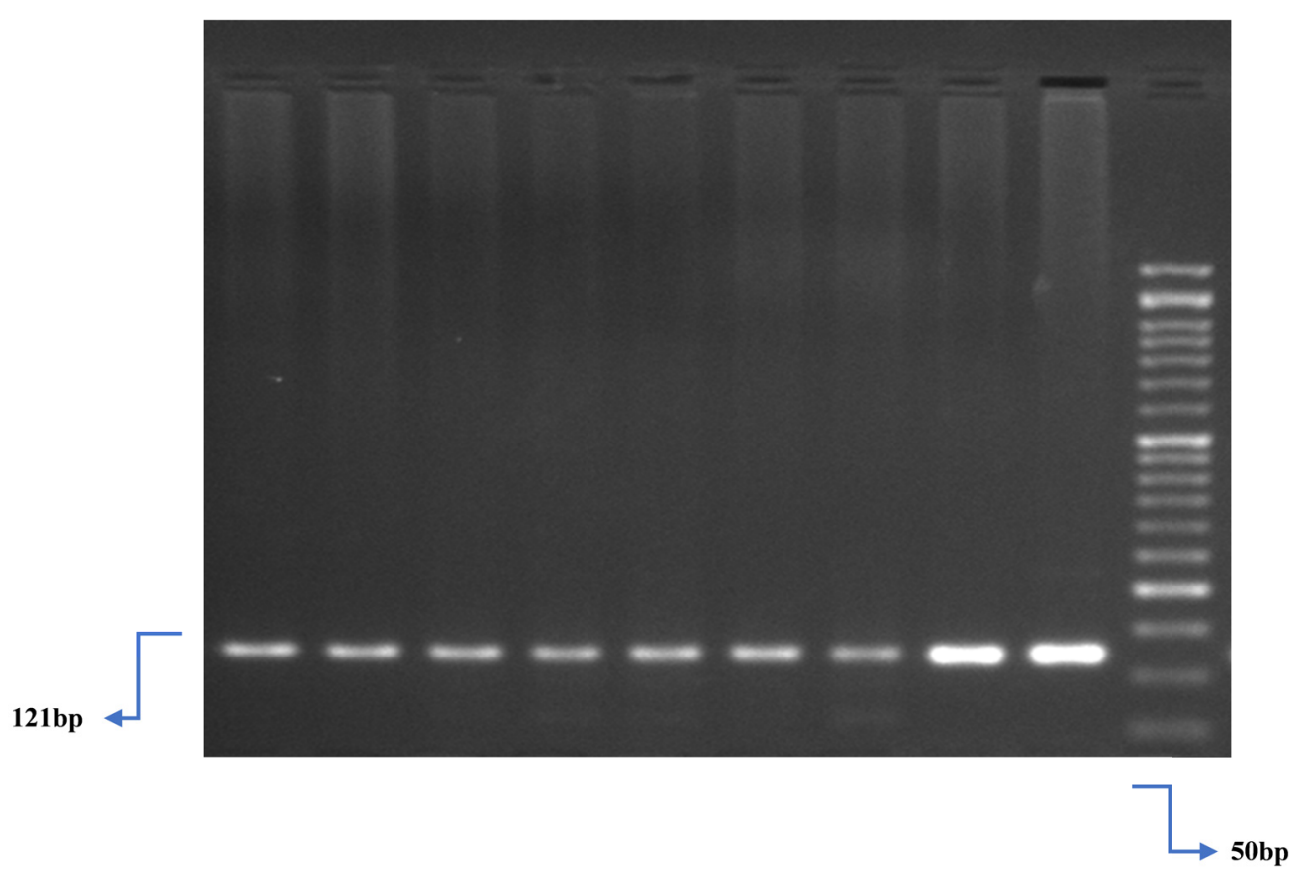

Figure 1. Electrophoresis showing PCR products (121 bp) on 1.8\% w/v agarose gel with ethidium bromide staining; DNA ladder: 50 bp

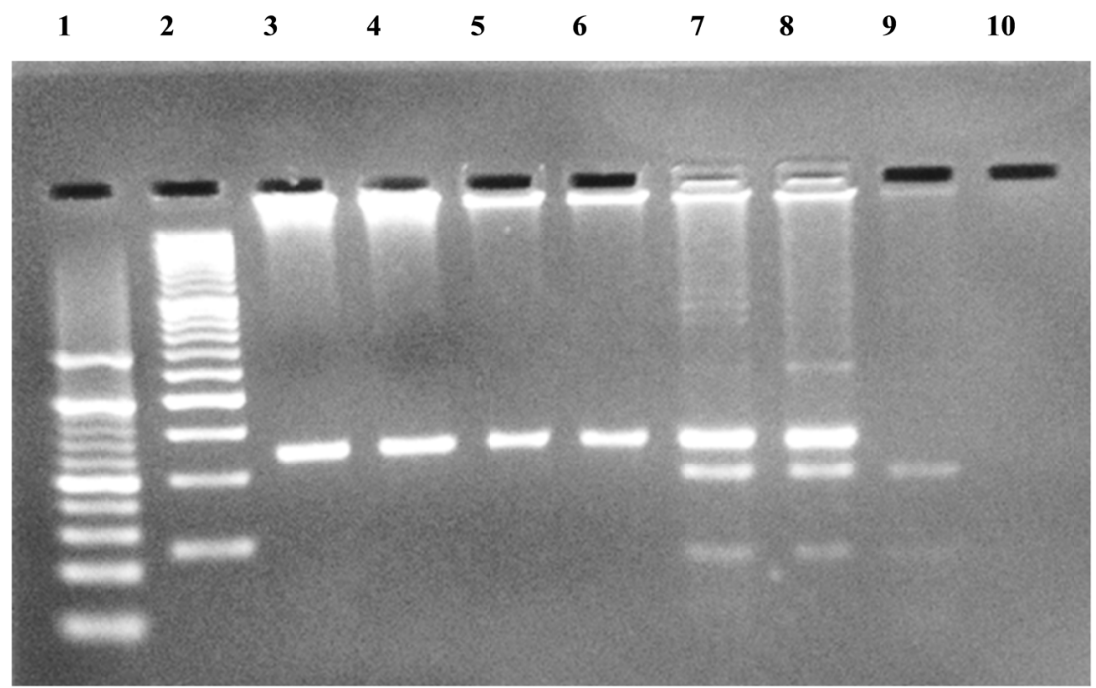

Figure 2. Results of PCR-RFLP analysis for CSN2 gene by DdeI on 3\% agarose gel. 1: marker 20 bp DNA ladder; 2: marker 50 bp DNA ladder; 3,4: PCR product (121 bp); 5,6: genotype A1A1 (121 bp); 7,8: genotype A1A2 (121 bp, 86 bp, 35 bp); 9: genotype A2A2 (86 bp, 35 bp); 10: Negative control 


\section{Frequency and Polymorphisms of CSN2 Genotypes in Greek Breed Cows (Holstein)}

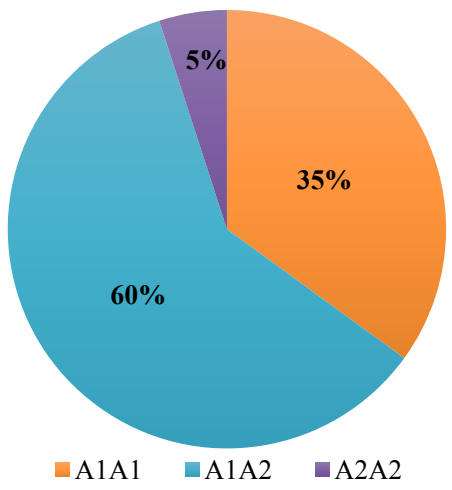

Figure 3. The above figure shows the results obtained in this study. Of the 120 cattle, $72(60 \%)$ showed triple bands of $121 \mathrm{bp}, 86 \mathrm{bp}$, and $35 \mathrm{bp}$, indicating the A1A2 genotype. $42(35 \%)$ cattle showed a single band at 121 $\mathrm{bp}$, indicating that they carried the A1A1 genotype. The remaining $6(5 \%)$ showed only two bands of 86 and 35 bps, indicating that they carried the A2A2 genotype. In conclusion, the A1A2 genotype predominates over the others

In the amplified product, the restriction site for the enzyme DdeI has been established. The resulting RFLP template from DdeI distinguishes three different band patterns/genotypes: A1A1 (121 bp), A2A2 (86 and $35 \mathrm{bp}$ ) and A1A2 (121, 86 and $35 \mathrm{bp}$ ). All these bands were clearly visible on $3 \%$ agarose gels except the $35 \mathrm{bp}$ band which could not be detected since very small. Allele A1 produced $121 \mathrm{bp}$ fragments, and allele A2 produced a 86 bp and $35 \mathrm{bp}$ fragments as the PCR-RFLP. The genotypic frequencies of these three variants varied across the breeds examined. It was detected 3 genotypes: 2 homozygote genotypes (A1A1, A2A2) and 1 heterozygote genotypes (A1A2). The heterozygote A1A2 genotype was the most frequent. Of the 120 cattle, $72(60 \%)$ showed triple bands of $121 \mathrm{bp}, 86 \mathrm{bp}$, and $35 \mathrm{bp}$ indicating the A1A2 genotype. The $42(35 \%)$ cattle showed a single band at $121 \mathrm{bp}$, indicating that they carried the A1A1 genotype. The remaining $6(5 \%)$ showed only two bands of 86 and 35 bps each, indicating that they carried the A2A2 genotype.

Frequencies of genotypes and alleles determined in the total population (120 animals) are presented in the Table 1. In the total population heterozygotes A1 A2 (0.6) were more predominant compared to homozygotes A1A1 (0.35) and A2A2 (0.05) which were the least frequent ones. As it can be inferred it can be observed two alleles A1 and A2 In the population included in the study the most common allelic variant of beta casein was A1, followed by A2, with frequencies of 0.65 and 0.35 , respectively. As shown in Table 2 it is observed high significance at $5 \%(\mathrm{a}=$ 0.05 ) and one degree of freedom since $p<0.01$.

Table 1. Frequencies of genotypes and alleles of the CSN2 gene in the population of cows

\begin{tabular}{llll}
\hline \multirow{2}{*}{ Frequency } & \multicolumn{3}{c}{ Genotypes $(\mathbf{n}=\mathbf{1 2 0})$} \\
\cline { 2 - 4 } & A1A1 & $\mathbf{A 1 A 2}$ & $\mathbf{A 2 A 2}$ \\
\hline Absolute & 42 & 72 & 6 \\
Relative & 0.35 & 0.60 & 0.05 \\
\hline
\end{tabular}

Table 2. Allele Frequencies and probability $(\mathrm{P})$ chi-square test of genotypes and alleles of the CSN2 gene in the population of cows

\begin{tabular}{lll}
\hline \multicolumn{2}{c}{ Alleles } & p-value \\
\hline A1 & A2 & $3.36 \times 10^{-6}$ \\
\hline $156(0.65)$ & $84(0.35)$ & 3.30 \\
\hline
\end{tabular}


Table 3. Occurrence of $\beta$-casein gene variants in Holstein-Friesian (HF) in Poland and Red in other countries (data sorted by increasing A1 allele frequency) (Kamiński et al., 2007)

\begin{tabular}{|c|c|c|c|c|c|}
\hline \multirow{2}{*}{ Breed } & \multirow{2}{*}{ Country } & \multicolumn{2}{|c|}{ Allele Frequency of $\beta$-Casein } & \multirow{2}{*}{$N$} & \multirow{2}{*}{ References } \\
\hline & & A1 & A2 & & \\
\hline \multirow{12}{*}{$\mathrm{HF}$} & Denmark & 0.266 & 0.614 & 415 & (Gustavsson et al., 2014) \\
\hline & The Netherlands & 0.28 & 0.50 & 1929 & (Visker et al., 2011) \\
\hline & The Netherlands & 0.029 & 0.69 & 1629 & (Heck et al., 2009) \\
\hline & Poland & 0.32 & 0.68 & 177 & (Cieślińska et al., 2012) \\
\hline & Poland & 0.35 & 0.65 & 650 & (Cieślińska et al., 2012) \\
\hline & Thailand & 0.363 & 0.602 & 231 & (Molee et al., 2011) \\
\hline & Italy & 0.371 & 0.546 & 1226 & (Massella et al., 2017) \\
\hline & Italy & 0.395 & 0.57 & 100 & (Chessa et al., 2013) \\
\hline & Poland & 0.40 & 0.60 & 143 & (Kamiński et al., 2006) \\
\hline & China & 0.432 & 0.459 & 133 & (Dai et al., 2016) \\
\hline & Turkey & 0.485 & 0.456 & 49 & (Dinc et al., 2013) \\
\hline & Iran & 0.50 & 0.50 & 119 & (Gholami et al., 2016) \\
\hline \multirow{3}{*}{ Red } & Sweden & 0.48 & 0.51 & 392 & (Gustavsson et al., 2014) \\
\hline & Denmark & 0.71 & 0.23 & 169 & (Bech and Kristiansen, 1990) \\
\hline & Poland & 0.53 & 0.47 & 201 & Present data \\
\hline
\end{tabular}

Note. Other variants of the $\beta$-casein gene are not included.

\section{Discussion}

Milk contains all the nutrients a young body needs to grow and is particularly rich in proteins and salts. Milk is the only food in nature that contains the high-protein protein known as casein. Casein-derived peptides enhance the body's natural defenses, regulate blood pressure and help fight stress. In the present study, we investigated the polymorphism of exon 7 of the CSN2 gene encoding bovine milk $\beta$-casein. Several studies have been conducted linking A1 polymorphism with the production of the opioid peptide BCM-7 associated with human health problems such as type 1 diabetes, autism, schizophrenia and heart disease. In contrast, milk with A2 polymorphism has been found not to cause similar problems in human health (Caroli, Chessa, \& Erhardt, 2009; Cies̈lińska et al., 2015; Elliott et al., 1999; Kumar et al., 2019; McLachlan, 2001; Woodford, 2007, 2011). To draw safe conclusions, the results of the present study were compared with similar studies on $\beta$-casein polymorphisms. The results of the present study showed that the A1A2 genotype predominates in relation to the A1A1 genotype. On the contrary, the A2A2 genotype is in a significant minority. Specifically, heterozygous cattle (A1A2) are $72(60 \%)$ with the A2 allele while homozygous cattle (A1A1) with the A1 allele are 42 (35\%). Only $6(5 \%)$ showed the A2A2 genotype. The results were that the A1A2 genotype outperformed the others. A similar study was conducted by Kumar et al. (2019) where blood was collected from 429 Frieswal cows. The results were that A1A2 genotype and A2 polymorphism predominated. Maximum A1A2 genotypic frequency was observed in $221(51.5 \%)$ samples, followed by 133 (31\%) A2A2 and 75 (17.5\%) A1A1 samples. Another survey with similar results was by Sodhi et al. (2018) participated 85 cattle of Ladakh region, India. Results showed that 82 (96.5\%) animals carried the A2A2 genotype and the rest (3.5\%) A1A2. None of the animals carried the A1A1 genotype. In conclusion, this region is dominated by the $\mathrm{A} 2$ allele. The results of the study were similar to those of Miluchová, Trakovická, \& Gábor, (2009). A total of 89 cattle were included. The results of the study showed that there were $27(30.34 \%)$ animals with A1A1 genotype, 46 (51.69\%) animals with A1A2 and 16 (17.97\%) animals with A2A2. Of the entire bovine population, the A2 allele was predominant. Another related study is by Miluchová et al. (2014) where 287 cattle from three different breeds participated. 111 belonged to the Simmental tribe, 89 Pinzgau and 87 Holstein. Results showed that in the Holstein breed, A1A1 genotype was detected in 12 (13.79\%) cows, A1A2 genotype in $40(45.98 \%)$ cows and A2A2 genotype in $35(40.23 \%)$ cows. In the Pinzgau breed, the A1A1 genotype was detected in $27(30.34 \%)$ cows, the A1A2 genotype in 46 (51.68\%) cows, and the A2A2 genotype in $16(17.98 \%)$ cows. Finally, in the Simmental breed, the A1A1 genotype was detected in $14(12.61 \%)$ cows, the A1A2 genotype in $37(33.33 \%)$ cows and the A2A2 genotype in 60 (54.06\%) cows. In conclusion, this study also dominates the A2 allele in all three cattle breeds. Taking into account the results of this study and the numerous studies that have been carried out, it can be concluded that A2 polymorphism predominated over A1 and that the beta-casein polymorphisms in the different cattle breeds are still highly variable, which have not been adequately researched. Of course, to draw safe conclusions a complete mapping of the beta-casein variants would have to be done in order to correlate the various qualitative and quantitative characteristics of the milk and 
also to the effects on human health.

\section{Conclusions}

Taking into account the results of the present study as well as studies conducted abroad, we conclude that the beta-casein polymorphisms in bovine breeds vary widely.

To our knowledge, as there is a lack of studies in Greece about the genetic polymorphism of b-casein in cows, this work serves as a preliminary study on the existing genetic polymorphisms of $b$ casein of our local cow breeds. Moreover, this study will play an important purpose in aiding selection of cows with respects to traits of milk quality.

\section{References}

Balteanu, V. A., Vlaic, A., Suteu, M., \& Carsai, T. C. (2010). A comparative study of major milk protein polymorphism in six Romanian cattle breeds. Bulletin of University of Agricultural Sciences and Veterinary Medicine Cluj-Napoca-Animal Science and Biotechnologies, 67(January 2010), 345-350. https://doi.org/ 10.15835/buasvmen-asb:67:1-2:5322

Bech, A. M., \& Kristiansen, K. R. (1990). Milk protein polymorphism in Danish dairy cattle and the influence of genetic variants on milk yield. J. Dairy Res., 57, 53-62. https://doi.org/10.1017/S0022029900026601

Boztepe, S., Aytekin, İ., \& Şahin, Ö. (2018). A1 and A2 Bovine Milk, the Risk of Beta-casomorphin-7 and Its Possible Effects on Human Health: (II) Possible Effects of Beta-casomorphin-7 on Human Health. Selcuk Journal of Agricultural and Food Sciences, 32(3), 640-645. https://doi.org/10.15316/sjafs.2018.147

Brooke-Taylor, S., Dwyer, K., Woodford, K., \& Kost, N. (2017). Systematic Review of the Gastrointestinal Effects of A1 Compared with A2 $\beta$-Casein. Advances in Nutrition: An International Review Journal, 8(5), 739-748. https://doi.org/10.3945/an.116.013953

Caroli, A. M., Chessa, S., \& Erhardt, G. J. (2009). Invited review: Milk protein polymorphisms in cattle: Effect on animal breeding and human nutrition. Journal of Dairy Science, 92(11), 5335-5352. https://doi.org/ $10.3168 /$ jds.2009-2461

Chessa, S., Bulgari, O., Rossoni, A., Ceriotti, G., \& Caroli, A. M. (2013). Bovine $\beta$-casein: Detection of two single nucleotide polymorphisms by bidirectional allele specific polymerase chain reaction (BAS-PCR) and monitoring of their variation. Open J. Anim. Sci., 03, 36-41. https://doi.org/10.4236/ojas.2013.31005

Cieślińska, A., Kostyra, E., Kostyra, H., Oleński, K., Fiedorowicz, E., \& Kamiński, S. (2012). Milk from cows of different $\beta$-casein genotypes as a source of $\beta$-casomorphin-7. International Journal of Food Sciences and Nutrition, 63(4), 426-430. https://doi.org/10.3109/09637486.2011.634785

Cies̈lińska, A., Sienkiewicz-Szłapka, E., Wasilewska, J., Fiedorowicz, E., Chwała, B., Moszyńska-Dumara, M., ... Kostyra, E. (2015). Influence of candidate polymorphisms on the dipeptidyl peptidase IV and $\mu$-opioid receptor genes expression in aspect of the $\beta$-casomorphin-7 modulation functions in autism. Peptides, 65, 6-11. https://doi.org/10.1016/j.peptides.2014.11.012

Dai, R., Fang, Y., Zhao, W., Liu, S., Ding, J., Xu, K., ... Meng, H. (2016). Identification of alleles and genotypes of beta-casein with DNA sequencing analysis in Chinese Holstein cow. J. Dairy Res., 83, 312-316. https://doi.org/10.1017/S0022029916000303

Davoodi, S. H., Shahbazi, R., Esmaeili, S., Sohrabvandi, S., Mortazavian, A. M., Jazayeri, S., \& Taslimi, A. (2016). Health-related aspects of milk proteins. Iranian Journal of Pharmaceutical Research, 15(3), 573-591. https://doi.org/10.22037/ijpr.2016.1897

Dinc, H., Ozkan, E., Koban, E., \& Togan, I. (2013). Beta-casein A1/A2, kappa-casein and beta-lactoglobulin polymorphisms in Turkish cattle breeds. Archives Animal Breeding, 56(1), 650-657. https://doi.org/10.7482/ 0003-9438-56-065

Elliott, R. B., Harris, D. P., Hill, J. P., Bibby, N. J., \& Wasmuth, H. E. (1999). Type I (insulin-dependent) diabetes mellitus and cow milk: Casein variant consumption. Diabetologia, 42(3), 292-296. https://doi.org/10.1007/ s001250051153

Farrell, H. M., Jimenez-Flores, R., Bleck, G. T., Brown, E. M., Butler, J. E., Creamer, L. K., ... Swaisgood, H. E. (2004). Nomenclature of the proteins of cows' milk (6th revision). Journal of Dairy Science, 87(6), 1641-1674. https://doi.org/10.3168/jds.S0022-0302(04)73319-6

Ferretti, L., Leone, P., \& Sgaramella, V. (1990). Long range restriction analysis of the bovine casein genes. 
Nucleic Acids Research, 18(23), 6829-6833. https://doi.org/10.1093/nar/18.23.6829

Gholami, M., Hafezian, S. H., Rahimi, G., Farhadi, A., Rahimi, Z., Kahrizi, D., ... Zargooshi, J. (2016). Allele specific-PCR and melting curve analysis showed relatively high frequency of $\beta$-casein gene A1 allele in Iranian Holstein, Simmental and native cows. Cell. Mol. Biol., 62, 138-143. https://doi.org/10.14715/ $\mathrm{cmb} / 2016.62 .12 .23$

Gustavsson, F., Buitenhuis, A. J., Johansson, M., Bertelsen, H. P., Glantz, M., Poulsen, N. A., ... Andrén, A. (2014). Effects of breed and casein genetic variants on protein profile in milk from Swedish Red, Danish Holstein, and Danish Jersey cows. J. Dairy Sci., 97, 3866-3877. https://doi.org/10.3168/jds.2013-7312

Haug, A., Høstmark, A. T., \& Harstad, O. M. (2007). Bovine milk in human nutrition-A review. Lipids in Health and Disease, 6, 1-16. https://doi.org/10.1186/1476-511X-6-25

Heck, J. M. L., Schennink, A., Van Valenberg, H. J. F., Bovenhuis, H., Visker, M. H. P. W., Van Arendonk, J. A. M., \& Van Hooijdonk, A. C. M. (2009). Effects of milk protein variants on the protein composition of bovine milk. J. Dairy Sci., 92, 1192-1202. https://doi.org/10.3168/jds.2008-1208

Jann, O., Ceriotti, G., Caroli, A., \& Erhardt, G. (2002). A new variant in exon VII of bovine $\beta$-casein gene (CSN2) and its distribution among European cattle breeds. Journal of Animal Breeding and Genetics, 119(1), 65-68. https://doi.org/10.1046/j.1439-0388.2002.00318.x

Kamiński, S., Cieślińska, A., \& Kostyra, E. (2007). Polymorphism of bovine beta-casein and its potential effect on human health. Journal of Applied Genetics, 48(3), 189-198. https://doi.org/10.1007/BF03195213

Kamiński, S., Ruść, A., \& Cieślińska, A. (2006). A note on frequency of A1 and A2 variants of bovine beta-casein locus in Polish Holstein bulls. J. Anim. Feed Sci., 15, 195-198. https://doi.org/10.22358/ jafs $/ 66892 / 2006$

Keating, A. F., Smith, T. J., \& Cairns, M. T. (2008). A note on the evaluation of a beta-casein variant in bovine breeds by allele-specific PCR and relevance to beta- casomorphin. Irish Journal of Agricultural and Food Research, 47(1), 99-104.

Kumar, A., Singh, R. V., Chauhan, A., Ilayakumar, K., Kumar, S., Kumar, A., ... Bhushan, B. (2019). Genetic association analysis reveals significant effect of $\beta$-casein A1/A2 loci on production \& reproduction traits in Frieswal crossbred cows. Biological Rhythm Research. https://doi.org/10.1080/09291016.2019.1571705

Massella, E., Piva, S., Giacometti, F., Liuzzo, G., Zambrini, A. V., \& Serraino, A. (2017). Evaluation of bovine beta casein polymorphism in two dairy farms located in northern Italy. Italian Journal of Food Safety, 6(3), 131-133. https://doi.org/10.4081/ijfs.2017.6904

McLachlan, C. N. S. (2001). $\beta$-casein A1, ischaemic heart disease mortality, and other illnesses. Medical Hypotheses, 56(2), 262-272. https://doi.org/10.1054/mehy.2000.1265

Miluchová, M., Gábor, M., \& Trakovická, A. (2014). Analysis of Beta-Casein Gene ( CSN2 ) Polymorphism in Different Breeds of Cattle. Scientific Papers: Animal Science and Biotechnologies, 47(2), 56-59.

Miluchová, M., Trakovická, A., \& Gábor, M. (2009). Analysis of Polymorphism of Beta Casein of Slovak Pinzgau Cattle By Pcr-Rflp for Allels a1 and a2. Zootehnie şi Biotehnologii, 42(2), 288-292.

Molee, A., Boonek, L., \& Rungsakinnin, N. (2011). The effect of beta and kappa casein genes on milk yield and milk composition in different percentages of Holstein in crossbred dairy cattle. Anim. Sci. J., 82, 512-516. https://doi.org/10.1111/j.1740-0929.2011.00879.x

Mølgaard, C., Larnkjær, A., Arnberg, K., \& Michaelsen, K. F. (2011). Milk and growth in children: Effects of Whey and Casein. Nestle Nutrition Workshop Series: Pediatric Program, 67(April 2015), 67-78. https://doi.org/10.1159/000325576

Saran, M., Gurao, A., Joshi, R. K., \& Kashyap, S. K. (2019). Prevalence of the Beta Case in Variants among Tharparkar, Rathi, Sahiwal, Kankrej and Cross Breed and its Influence under Selective Pressure. International Journal of Current Microbiology and Applied Sciences, 8(03), 1842-1848. https://doi.org/ 10.20546/ijcmas.2019.803.218

Sebastiani, C., Arcangeli, C., Ciullo, M., Torricelli, M., Cinti, G., Fisichella, S., \& Biagetti, M. (2020). Frequencies evaluation of $\beta$-Casein gene polymorphisms in dairy cows reared in central Italy. Animals, 10(2), 1-7. https://doi.org/10.3390/ani10020252

Sodhi, M., Kataria, R. S., Niranjan, S. K., Verma, P., Swami, S. K., ... Mukesh, M. (2018). Sequence 
Characterisation and Genotyping of Allelic Variants of Beta Casein Gene Establishes Native Cattle of Ladakh to be a Natural Resource for A2 Milk. Defence Life Science Journal, 3(2), 177. https://doi.org/ $10.14429 /$ dlsj.3.12574

Sun, Z., Zhang, Z., Wang, X., Cade, R., Elmir, Z., \& Fregly, M. (2003). Relation of $\beta$-casomorphin to apnea in sudden infant death syndrome. Peptides, 24(6), 937-943. https://doi.org/10.1016/S0196-9781(03)00156-6

Visker, M. H. P. W., Dibbits, B. W., Kinders, S. M., Van Valenberg, H. J. F., Van Arendonk, J. A. M., \& Bovenhuis, H. (2011). Association of bovine $\beta$-casein protein variant I with milk production and milk protein composition. Anim. Genet., 42, 212-218. https://doi.org/10.1111/j.1365-2052.2010.02106.x

Woodford, K. B. (2007). A2 milk, farmer decisions, and risk management. Proceedings of the 16th International Farm Management Congress: Peer reviewed papers (pp. 641-648). England: International Farm Management Association. Retrieved from http://researcharchive.lincoln.ac.nz/dspace/handle/10182/417

Woodford, K. B. (2011). Milk Proteins and Human Health: A1 versus A2 Beta-casein. General Practitioners Conference, Sydney, 22 May 2011, 1-6. http://www.dr-petrek.eu/documents/HWE.xls

\begin{abstract}
Abbreviations
RFLP: restriction fragment length polymorphism; $\beta$-LG: beta-lactoglobulin; a-LA: $\alpha$ lpha-lactalbumin; BSA: bovine serum albumin; LF: lactoferrin; LP: lactoperoxidase; Igs: immunoglobulins; BCM-9: beta-casomorphin-9; BCM-7: beta-casomorphin-7; EDTA: ethylene diamine tetra-acetic acid.
\end{abstract}

\title{
Copyrights
}

Copyright for this article is retained by the author(s), with first publication rights granted to the journal.

This is an open-access article distributed under the terms and conditions of the Creative Commons Attribution license (http://creativecommons.org/licenses/by/4.0/). 